\title{
THE VERIFICATION OF THE BEST-FIT EQUATION TO PREDICT SPATIAL SEDIMENTATION RATES AT LOAGAN BUNUT LAKE, MIRI, SARAWAK
}

\author{
R.B. Dagang ${ }^{1}$, S. Lau $^{2}$, and A.K. Sayok ${ }^{2}$ \\ 1. Swinburne University of Technology, Sarawak, Malaysia \\ 2. Universiti Malaysia Sarawak, 94300 Kota Samarahan, Sarawak, Malaysia \\ E-mail: rdagang@swinburne.edu.my
}

\begin{abstract}
Although a number of problems in environmental science deal with biology, chemistry and social issues, the applications of physics are also very important. In this paper, the best-fit model to predict spatial sedimentation rates at Loagan Bunut Lake is verified using conservation of mass and comparative equation. The lake is a flood plain lake that is located within the boundaries of Loagan Bunut National Park in the northeastern part of the state of Sarawak. Twenty two cylindrical traps were installed at the lake. The traps were placed in November 2005 until April 2008. Each sample was collected after about four to five months of deployment. Dry sedimentation rates of the traps and their linear distances from Trap 1 located at the confluencet of Bunut River were measured.
\end{abstract}

Key words: environmental physics, sedimentation rate, conservation of mass, Loagan Bunut Lake.

\section{Introduction}

Loagan Bunut is a fresh water lake situated within the boundary of Loagan Bunut National Park, at the northeastern part of the state of Sarawak. It covers $6 \%$ of the Park area. Specifically, the lake area is between Tinjar River and Teru River of the Baram Basin flood plain. It has its own basin which is mainly connected with Teru catchments by about 6.6 km of Bunut River.

About $61.9 \%$ of the catchments are Stateland on which logging licenses have been issued and where cultivation by local community takes place. Satellite images show a high road density in relatively steep areas [1].
The Teru catchment is made up of plantations and active subsistence farming areas [2].

To the locals, the Berawan, the lake and its surrounding areas play an important livelihood support system and place of abode for generations. To the Sarawak State, the lake and its surrounding have economic value for its unique hydrologic phenomena, exotic fish species, water birds, medicinal plants and rich local culture that are marketable in terms of tourism.

Even though the retaining of water and the trapping of sediment at Loagan Bunut are natural downstream flood and sedimentation controller, an alarmingly high rate of sedimentation at the lake accelerates the filling of the lake which threatens its functions, natural physical, hydrological phenomena and biodiversity. The lake was experiencing 27 years of rapid sedimentation and it was estimated to be infilled completely within less than 60 years [3]. Reports have mentioned that the sediment flux along the main feeder stream, the Bunut River and in the lake were $15 \mathrm{~kg} \mathrm{~m}^{-2} \mathrm{y}^{-1}$ and $0.6 \mathrm{~kg} \mathrm{~m}^{-2}$ $\mathrm{y}^{-1}$ respectively [4].

The authors of this paper are therefore interested to contribute by verifying the best-fit model that can be used to predict sedimentation rates at the distance $0-600 \mathrm{~m}$ from the Bunut River.

\section{Materials and methods}

\section{Sediment traps}

The study site and the sampling stations are as shown in Fig. 1. All the sampling stations were recorded using numbers and clearly marked on the site with bamboo stilts where the sediment traps were tied. The trap's positions and distances from Trap 1 were recorded (Table 1). 